The medical committee began their reply by a most comprehensive yet succinct presentation by Dr. John K. Mitchell, followed by Dr. Wm. M. Welsh, who gave, in addition to statis tics drawn from German, A ustrian and other sources, his own enormous personal experience of between five and six thousand cases of smallpox, which were published in 1894, and drew careful deductions from his studies of the protecting power of vaccination. Dr. James C. Wilson made a brief but pungent reply to the points claimed by the introducers of the bill, in a most scholarly and eloquent fashion. Dr. Hamill and myself were called upon for remarks, but we felt that the matter had been amply elaborated.

The members of the committee assured us we need have no fear of further difficulties at this time, as the introducers of the bill made so feeble a showing that they offered no testimony of a convincing character whatsoever. Indeed, it seemed to be a needlessly powerful array of scientific opinion and medical experience against a pitiably feeble effort of a few misguided men who obviously had not studied the matter fully. However, two years before, at the same place, a similar bill was almost made law, at which time the medical societies had no knowledge of the measure to be introduced, and it was only due to the good sense of the committee that the measure was then defeated.

It is most important when such movements are initiated that the medical men meet them fairly and promptly, otherwise much trouble may result, and the community be deprived of one of the most important safeguards against disease, death, and commercial paralyeis.

Finally, it is a curious commentary on medical apathy that the only city in the State to send any organized opposition to this insidious measure was Philadelphia. The towns and other large cities of the State failed to raise their hands and, except for the earnest efforts of these busy men the measure might have been passed, not on its merits but because there was no one to reply.

$$
\text { J. Madison TaYlor, M.D. }
$$

\section{Congenital Deformities of Hand.}

Philadelphia, Pa., March 21, 1899.

To the Editor:-Referring to Dr. F. R. Sherwood's very meritorious article in the Journal of March 11, on the above subject, I am constrained to contribute this brief record of an observation, made en passant as it were, which may possess some interest for the doctor, and for some other readers.

It was several months ago that, while riding in a trolley-car, I saw sitting upon its mother's lap near by, a child apparently about three years of age, having five distinct fingers on each hand-no thumbs. In place of the latter there were two prehensile fingers having each three phalanges, and quite closely resepnbling the apposed forefingers respectively, in size, shape, length, and mobility. The finger thumbs seemed to serve the bands with as much freedom of motion, prehension and adaptsbility as ordinary thumbs, as I could unmistakably detect while in a sufficiently favorable position to notice the child's movements without seeming to be too obtrusive.

$$
\text { Very respectfully, }
$$

Howard S. A NDERS, M.D.

Largin in Gonorrhea.-L. Fürst of Berlin warmly endorses largin and protargol in the treatment of gonorrhea muliebrie, considering the former more strongly bactericidal while still possessing all the other advantages of protargol (protargol 8.3 per cent. silver, largin 11.01 silver). He keeps the patient very quiet in bed for three weeks, as he finds success impossible with ambulatory treatment, and starts above the seat of the infection to prevent ascending infection, commencing by irri. gating the uterine cavity when the lesion is at the cervix.Derm. Ztft., February.

\section{Eurrent Mredical siterature.}

Medical Record (N, Y.), March 25.

1.-Neurasthenia, Etiology and Treatment of. Joseph Collins and Carlin Phillips.

2.-Eruptions of Face Due to Nasal Pressure. G. D. Murray.

3.-Cocain, Notes on. Walter P. Jenmey. Bottini Operation, Inflating the Bladder with Air Preliminary to.
Bransford Lewis.

Medical News (N. Y.), March 25.

5.-Abscess of Lung, with Clinical Data. Henry L. Elsner.

6 -Occipito-Posterior Positions in Labor Cases, the Diagnosis and Management of. Charles H. Glidden.

7.-Nasal Catarrh in Children. Clarence C. Rice.

New York Medical Journal, March 25.

8.-U. S. Army Ration and its Adaptability for Use in Tropic Climates. Louis L. Seaman.

On a Polymorphous Cerebral Tumor Containing Tubercles and ubercle Bacilli. Claribel Cone.

10.-Antiphthisic Serum, a Further Report on. A. Mansfield Holmes.

11.-Bathing a Regiment. H. M. Cohen.

2.-Chronic Ulcers of the Leg, Treatment of. John B. Corsiglia. Boston Medical and Surgical Journal, March 23.

14.-Phlegmasia Dolens, or Milk-Leg in Typhoid Fever. J. M. DaCosta.

16.--Probing of Nasal Duct from Nose. Arthur J. Shaw. Philadelphia Medical Journal, March 25.

17.-Dysphagia and Cough, Treatment of, Especially in Tuberculosis. W. Frudenthal.

Neurotrophic Function, bearing of, on Cutaneous Conditions. Samuel Wolfe.

19. - Hepatic Sclerosis, Some Signs of. A. L. Benedict.

.-Poisoning by Roaches, Report of a Case. J. Murray Johnson. Medical Review (St. Louis), March 25

22.-Trifacial Neuralgia (Surgical) Treatment of, with Report of Case of Removal of Gasserian Ganglion. N. B. Carson. Cincinnati Lancet Clinic, March 25.

23.-Puerperal Eclampsia. Robert W. Stewart.

Journal of Medicine and Science, March.

24.-Bovine Tuberculin Tests. George H. Bailey. Journal of Nervous and Mental Diseases, March.

25.-Deep Reflexes of Lower Extremities, Points of Special Interest in the

Study of. Charles K. Mills.
26.-Stereognostic Sense, Conrribution to Knowledge of. Joseph Sailer. American Gynecological and Obstetrical Journal, March.

27.-Myomectomy by a New Method. Alex. J. C. Skene.

8.- Malposition of Uterus, Electricity in Mechanic Treatment of Franklin H. Martin.

29.-Malposition of Uterus, Use of Massage in. William H. Rumpf. Displacement of Uterus, Tampons and Pessaries in Treatment of.

31-Recent Pelvic Surgery, Relations of Pelvic Cellulitis to. Ely Van de Warker.

Robert L. Dick Segment

33.-An Elective Cesarean Section. G. M. Boyd.

34.--Ethyl Bromid, Value of, in Gynecology and Obstetrics. Frank C. Hammond.

Medicine, March.

35.-Skin, Transplantation of, and Origin of Pigment. Leo Loeb.

36.-Foreign Bodies in Maxillæ, Implantation of. Carl Theodor Gramm. Rheumatism, Differentiation of Chronic orms Jouis Faugéres Bishop.

39.- - Gelatin in Aneurysm, Subcutaneous Injections of. Harold N. Moyer. Maryland Medical Journal, March 25.

40.-Croupous Pneumonia, Treatment with Hot Water Bags. Louis Koli-

41.-Vaccin Virus, Purified, W. F. Elgin.

International Medical Magazine, March.

42.-Phthisis, Notes on Cases of, witlı Peculiar Cardiac Physical Signs. Wm. Ewart

3.--Typlititis, a Medical Study. A, L. Benedict.

44.-Chronic Plumbism from Drinking Water. L. Smirnow. American Journal of the Medical Sciences, March.

45. Sporadic Trichinosis, Clinical Features of. Wm. Osler

16.- Syringomvelia with Unusual Symptoms, a Case of. Wm. Norton Bullard and John Jenks Thomas.

47.--Typhoid Fever Complicated by Cholecystitis, Tapping of Gall-BladC. B. Camac.

48.-Dupuytren's Contraction of Palmar and Digital Fascia, a Clinical Study of. J. B. Nichols.

9.-Empyema of Frontal Sinuses and Intracranial Infection. C. L. Gibson. Trachea and Bronchi to Thoracic Wall Determined by. Josepli A. Blake.

sematrophy of Brain wit
sonality. Pearce Bailes.

Medical Register (Richmond, Va.), March.

2.-Meningitis, Cerebrospinal Followed by Gangrene of Feet. W. P. Matthers.

Columbus Medical Journal, March.

53.--Extra Cterine Pregnancy, Clinical Phases of. O. M. Cardier.

54.--Epithelioma of Penis, a Case of. N, E. Aronstam.

Southern Medical Record (Atlanta, Ga.), March.

-Tubercular Peritonitis, Diagnosis and Treatment of. William L. Robinson.

56. - Phthisis Pulmonalis, Creosote in. L. H. Warner.

Pediatrics, March 17.

57.-Multiple Sarcomata in a Child. Frederick A. Packard. 